$$
\begin{gathered}
\text { 사료 공급 횟수 및 만복 공급율이 비단잉어 홍백 } \\
\text { 치어의 성장 및 체조성에 미치는 영향 } \\
\text { 김이오·이상민 }{ }^{*} \\
\text { 충청북도내수면연구소, }{ }^{1} \text { 강릉원주대학교 해양생명공학부 }
\end{gathered}
$$

\title{
Effects of Feeding Frequency and Satiation Rate on the Growth and Body Composition of Red- and White-colored Carp, Cyprinus carpio var. koi
}

\author{
Yi Oh Kim and Sang-Min Lee ${ }^{1 *}$ \\ Department of Inland Fisheries Research Institute, Chung-Ju 380-250, Korea \\ ${ }^{I}$ Faculty of Marine Bioscience and Technology, Gangneung-Wonju National University, \\ Gangneung 210-702, Korea
}

We investigated the proper feeding frequency and satiation rate for the growth of red- and white-colored carp fingerlings in a feeding experiment. Triplicate groups of fish averaging $6.3 \mathrm{~g}$ were fed diets at four feeding frequencies $(1,2,3$, or 4 meals a day) and two satiation rates (satiation and $80 \%$ satiation) for 6 weeks. The survival of the fish was not affected by either the feeding frequency or the satiation rate. The weight gain, feed efficiency, and protein efficiency ratio of fish were affected by the feeding frequency and satiation rate, and increased significantly with both. The feed efficiency and protein efficiency ratio with satiation feeding of fish fed four meals a day did not differ from those of fish fed three meals a day. The daily feed intake was affected by the feeding frequency and satiation rate. The moisture, crude lipid, and ash contents of whole body were affected by the feeding frequency. Moisture and crude lipid contents were affected by feeding satiation. Based on these results, we conclude that the proper feeding frequency and satiation rate for the optimum growth of red- and white-colored carp fingerlings is four meals a day with satiation feeding.

Key words: Red- and White-colored carp, Feeding frequency, Satiation rate, Growth

$$
\text { 서 론 }
$$

대중화된 취미생활 중 관상어 사육은 매우 높은 비중을 차지한다(Hoff, 1993). 세계적으로 700여종의 어류가 관상 목 적으로 생산되며, 이들 대부분은 미국 플로리다와 동남아시아 에서 생산된다(Chapman et al., 1997). 관상용 어류 중에서 비단 잉어에 대한 관심이 높은데, 비단잉어를 키우려는 관상애어가 의 수가 증가하고 있기 때문에 고품질의 비단잉어 생산이 중요하다(Hancz et al., 2003). 국내 비단잉어는 충북, 전남 그리 고 경남 등 전국에서 생산되고 있으며, 규모가 큰 곳은 충북 진천관상어조합으로 1991년 영어조합법인이 설립되어 미국 및 유럽 등에 수출을 하고 있다. 향후 FIA체결로 정부의 농지 보존 대책이 완화되고 농업인들의 농산물에 대한 국제경쟁력 등을 고려해 볼 때, 비단잉어는 경쟁력이 높을 것으로 기대된다.

비단잉어를 포함한 관상어 사육에 있어, 그들의 성장 속도 는 중요하게 고려되지 않고 있으며, 심지어는 성장이 느린 것이 좋다고 알려져 있다. 하지만 관상애어가들의 수족관에서 사육 되는 관상어와는 달리 관상어 판매를 목적으로 하는 양식장에 서는 상품크기까지 빨리 키워야 가격을 높게 받을 수 있기 때문에 관상어의 성장은 중요한 고려 사항 중에 하나이다.

\footnotetext{
*Corresponding author: smlee@gwnu.ac.kr
}

어류 양식에 있어서 사료 공급체계는 사료효율 및 성장에 직접적으로 영향을 미치는 중요한 요소이다(Lee et al., 2000; $\mathrm{Ng}$ et al., 2000). 적절한 사료 공급체계가 확립되어 있지 않을 경우에는 영양소의 이용효율이 달라질 수 있기 때문에 적정 사료 공급횟수와 공급량을 결정하는 것은 양식생산량의 향상 과 수질오염의 감소를 위해 매우 중요하다 $(\mathrm{Ng}$ et al., 2000 ; Seo et al., 2005a). 잉어의 사료 공급(Abdelghany and Ahmad, 2002; Biswas et al., 2006a, b; Cho et al., 2001)에 대한 연구가 수행된 바 있지만, 비단잉어에 대한 사료 공급체계에 관한 연구는 없는 실정이다. 본 연구는 비단잉어 홍백 치어 사육시 사료 공급횟수 및 공급율이 성장 및 체성분에 미치는 영향을 조사하기 위해서 수행되었다.

$$
\text { 재료 및 방법 }
$$

\section{실험어 및 사육관리}

비단잉어는 충청북도 내수면 연구소에서 종묘 생산된 치어 를 사용하였으며, 실험시작 2 주전부터 시판 부상사료를 하루 2 회 공급하면서 예비 사육하였다. 예비 사육 후, 평균 체중 $6.3 \mathrm{~g}$ 의 비단잉어 치어를 $100 \mathrm{~L}$ 사각수조 (수용적: $60 \mathrm{~L}$ )에 40 마리씩 3 반복으로 임의로 수용하였다. 실험사료로 시판되 
고 있는 담수어용 부상 배합사료 (조단백질 $46.0 \%$, 조지질 $9.2 \%$ )를 사용하였다. 하천수를 각 실험수조에 $2 \mathrm{~L} / \mathrm{min}$ 가 되도 록 조절하여 흘려주었으며, 수조마다 에어스톤을 설치하여 산소를 공급해 주었다. 사료 공급량은 만복 공급구의 경우 실험어가 먹을 때까지 손으로 던져주었으며, 제한 공급구는 만복 공급구의 $80 \%$ 를 공급하였다. 사료 공급 횟수는 공급율에 대하여 각각 1 일 4회 (09:00, 12:00, 15:00, 18:00), 1일 3회 (09:00, 13:00, 18:00), 1일 2회 (09:00, 18:00) 및 1일 1회 (09:00) 로 설정하였다. 실험 개시시와 종료시에 측정 전일 절식시킨 후 각 실험 수조에 수용된 실험어 전체 무게를 측정하였으며, 사육기간 동안의 수온은 $26 \pm 1.0^{\circ} \mathrm{C}$ 였다.

\section{성분분석}

실험 종료시에는 24시간 절식시킨 각 실험수조의 비단잉어 치어를 즉사시켜 분석을 위해 냉동보관 $\left(-75^{\circ} \mathrm{C}\right)$ 하였다. 실험 사료 및 어체의 일반 성분은 표준 방법에 따라 분석하였는데, 조단백질 $(\mathrm{N} \times 6.25)$ 은 Auto Kjeldahl System (Buchi B-324/ $435 / 412$, Switzerland)을 사용하여 분석하였고, 조지질은 ether 를 사용하여 추출하였으며, 수분은 $105^{\circ} \mathrm{C}$ dry oven에서 6시간 동안 건조 후 측정하였고, 회분은 $600^{\circ} \mathrm{C}$ 에서 4 시간 동안 태운 후 정량 하였다.

\section{통계처리}

결과의 통계 처리는 SPSS program (SPSS, Michigan Avenue, Chicago, IL, USA)을 사용하여 One-way ANOVA-test를 실시 한 후, Duncan's multiple range test (Duncan, 1955)로 평균간의 유의성을 검정하였으며, Two-way ANOVA-test로 사료 공급 횟수와 공급율에 대한 상관요인을 분석하였다.

Table 1. Growth performance and feed efficiency of juvenile red- and white-colored carp fed diets with different feeding frequency and satiation rate for 6 weeks ${ }^{1}$

\begin{tabular}{lcccc}
\hline $\begin{array}{l}\text { Feeding } \\
\text { frequency/day }\end{array}$ & $\begin{array}{c}\text { Feeding } \\
\text { satiation }(\%)\end{array}$ & $\begin{array}{c}\text { Weight gain } \\
(\%)^{2}\end{array}$ & $\begin{array}{c}\text { Feed efficiency } \\
(\%)^{3}\end{array}$ & $\begin{array}{c}\text { Protein efficiency } \\
\text { ratio }^{4}\end{array}$ \\
\hline One meal & 80 & $-5.0 \pm 0.38^{\mathrm{a}}$ & $-26.7 \pm 1.52^{\mathrm{a}}$ & $-0.58 \pm 0.032^{\mathrm{a}}$ \\
& 100 & $-0.6 \pm 0.34^{\mathrm{a}}$ & $-2.4 \pm 1.39^{\mathrm{b}}$ & $-0.05 \pm 0.031^{\mathrm{b}}$ \\
Two meals & 80 & $5.6 \pm 0.48^{\mathrm{b}}$ & $16.3 \pm 1.05^{\mathrm{c}}$ & $0.35 \pm 0.023^{\mathrm{c}}$ \\
& 100 & $14.6 \pm 1.22^{\mathrm{c}}$ & $32.6 \pm 1.56^{\mathrm{d}}$ & $0.71 \pm 0.034^{\mathrm{d}}$ \\
Three meals & 80 & $17.6 \pm 2.66^{\mathrm{cd}}$ & $37.4 \pm 3.54^{\mathrm{d}}$ & $0.81 \pm 0.077^{\mathrm{d}}$ \\
& 100 & $26.4 \pm 2.52^{\mathrm{e}}$ & $44.1 \pm 1.38^{\mathrm{e}}$ & $0.96 \pm 0.029^{\mathrm{e}}$ \\
Four meals & 80 & $21.9 \pm 0.72^{\mathrm{de}}$ & $43.5 \pm 1.04^{\mathrm{e}}$ & $0.95 \pm 0.020^{\mathrm{e}}$ \\
\hline Two-way ANOVA & 100 & $32.0 \pm 2.96^{\mathrm{f}}$ & $49.1 \pm 3.02^{\mathrm{e}}$ & $1.07 \pm 0.067^{\mathrm{e}}$ \\
Feeding frequency $(\mathrm{F})$ & $P<0.001$ & $P<0.001$ & $P<0.001$ \\
Feeding satiation $(\mathrm{S})$ & $P<0.001$ & $P<0.001$ & $P<0.001$ \\
F $\times$ S & & $P<0.5$ & $P<0.02$ & $P<0.002$ \\
\hline
\end{tabular}

${ }^{1}$ Values (mean \pm SE of three replications) in the same column not sharing a common superscript are significantly different $(P<0.05)$.

${ }^{2}$ (Final body weight - initial body weight $) \times 100 /$ initial body weight.

${ }^{3}$ Fish wet weight gain $\times 100 /$ feed intake (dry matter).

${ }^{4}$ Fish wet weight gain/protein intake.

\section{결과 및 고찰}

평균 체중 $6.3 \mathrm{~g}$ 의 비단잉어 홍백 치어에게 사료 공급 횟수 와 만복 공급율을 달리하여 배합사료를 6주간 공급한 후의 증중율, 사료효율 및 단백질효율을 Table 1에 나타내었다. 사 육실험 기간 동안의 모든 실험구의 생존율은 $100 \%$ 였다. 증중 율, 사료효율 및 단백질효율은 사료 공급 횟수와 공급율에 모두 영향을 받았으며 $(P<0.001)$, 사료 공급 횟수와 공급율이 증가함에 따라 증가하는 경향을 보였다. 제한 공급구에서 사 료 공급 횟수가 증가함에 따라 증중율은 1 일 4회 공급구까지 증가하였으나 1 일 3 회 공급구와는 유의차가 없었다 $(P>0.05)$. 만복 공급구에서는 사료 공급 횟수가 증가함에 따라 증중율이 증가하여 1 일 4회 공급구가 가장 좋은 결과를 나타내었다. 1 일 1 회 공급구를 제외하고 동일한 공급횟수에서의 증중율은 만복 공급구가 제한 공급구보다 유의하게 높았다 $(P<0.05)$. 제한 공급구에서 사료효율 및 단백질효율은 사료 공급 횟수가 증가함에 따라 유의하게 증가하였다 $(P<0.05)$. 만복 공급구의 경우, 사료 공급 횟수가 증가함에 따라 사료효율 및 단백질효 율은 1 일 3 회 공급구까지 증가하였다. 동일한 공급횟수에서는 1 일 4회 공급구를 제외하면 사료효율 및 단백질효율이 만복 공급구가 제한 공급구보다 유의하게 높은 값을 나타내었다 $(P<0.05)$.

경제적이고 환경친화적인 비단잉어 양식을 위해서는 적정 사료 공급 횟수와 공급율을 조사하는 것이 매우 중요하다. 양식경영비의 높은 비중을 차지하는 사료를 효율적으로 공급 하는 것은 어류의 성장 및 사료효율 증가로 경제적인 면에서 이익이 될 뿐 아니라 사료 유래의 수질오염원을 감소시킬 수 있어 환경적인 측면에서의 장점을 얻을 수 있다. 본 실험에 서 만복 공급구가 제한 공급구에 비해 성장이 높은 것으로 보아, 비단잉어 치어를 양성할 때 사료를 만복으로 공급하는 것이 더 효율적임을 알 수 있다. 이와 같이 공급율이 낮으면 성장이 저하되는 것은 타 어종들 (Mihelakakis et al., 2002; $\mathrm{Ng}$ et al., 2000)에서도 보고되는 일반적인 현상으로서 성장에 필요로 하는 에너지와 영양소 요구량과 관련되어 있다 (Hung et al., 1987; Kim et al., 2009). 평균체중 55-90 g 넙치 치어 (Seo et al., 2005a, b)는 만복 공급이 양호한 결과를 보인 반면, 평균체중 $25 \mathrm{~g}$ 전후인 조피볼락 치어 (Lee, 1997)의 적정 공급 율은 만복의 $80 \%$ 전후라고 보고되었다. 일반잉어 (Cho et al., 2001)를 대상으로 한 실험에서는 만복의 $88 \%$ 공급구가 $78 \%$ 공급구보다 성장이 높았으며, $100 \%$ 공급구와 유의차가 없었다고 보고하였다. 이처럼 사료의 적정 공급량은 어종, 식성, 어류의 크기, 사료종류 및 사육환경 등에 따라 달라질 수 있기 때문에 이에 대한 고려가 필요하다 $(\mathrm{Ng}$ et al., 2000).

어류의 최대성장을 위한 적정 사료 공급 횟수는 어종, 어체 크기, 사료 조성 및 사료 공급율 등에 따라 다르다고 보고되어 있다 (Wang et al., 1998; Company et al., 1999). 많은 연구자들 은 사료의 공급횟수가 증가함에 따라 성장과 사료 공급량이 증대된다고 보고하고 있다 (Kayano et al., 1993; Dwyer et al., 2002). 본 연구 결과에서도 공급횟수가 증가할수록 좋은 성장 
결과를 나타내었다. 타 어종의 적정 사료 공급 횟수를 조사한 연구들에서, 1 년생 무지개송어 $(400-700 \mathrm{~g})$ 의 성장은 1 일 4회 공급구까지 증가하였으며 (Ruohonen et al., 1998), 틸라피아 (183 g)는 1일 3회 (Riche et al.,, 2004), 조피볼락 (6 g)은 1일 1 회 (Lee et al., 2000)가 적합하다고 보고되었다. Biswas et al. (2006a)은 인도산 잉어류인 rohu $(0.47 \mathrm{~g})$ 의 성장은 1일 3 회 공급구까지 계속 증가하는 경향을 보인다고 하였다. 본 연구의 1 일 1 회 사료 공급구는 실험 시작보다 실험종료시의 체중이 감소하였는데, 이는 사료 공급량의 부족으로 성장에 필요한 영양소 및 에너지가 부족하였기 때문으로 판단된다.

Table 2. Feed intake and nutrient retention of juvenile redand white-colored carp fed diets with different feeding frequency and satiation rate for 6 weeks ${ }^{1}$

\begin{tabular}{|c|c|c|c|c|c|c|}
\hline $\begin{array}{l}\text { Feed } \\
\text { frequ }\end{array}$ & $\begin{array}{c}\text { Feeding } \\
\text { satiation } \\
(\%)\end{array}$ & $\begin{array}{l}\text { Daily feed } \\
\text { intake }(\%)^{2}\end{array}$ & $\begin{array}{l}\text { Dail } \\
\text { int }\end{array}$ & $\begin{array}{l}\text { Daily lipid } \\
\text { intake (\%) }\end{array}$ & $\begin{array}{c}\text { Protein } \\
\text { retention } \\
(\%)^{3}\end{array}$ & $\begin{array}{l}\text { Lipid } \\
\text { retention } \\
(\%)^{3}\end{array}$ \\
\hline \multirow{2}{*}{ One meal } & 80 & $0.5 \pm 0.01^{\mathrm{a}}$ & $0.25 \pm 0.007^{\mathrm{a}}$ & $0.05 \pm 0.001^{a}$ & $-8.5 \pm 0.53^{a}$ & $-20.2 \pm 1.57^{\mathrm{a}}$ \\
\hline & 100 & $0.7 \pm 0.02^{b}$ & $0.32 \pm 0.007^{\mathrm{b}}$ & $01^{a}$ & -0.4 & $-2.1 \pm 1.19^{b}$ \\
\hline \multirow[b]{2}{*}{ Two meals } & 80 & $0.9 \pm 0.02^{c}$ & $0.43 \pm 0.01^{c}$ & $0.09 \pm$ & $5.5 \pm 0.38^{c}$ & $14.3 \pm 1.26^{c}$ \\
\hline & 100 & $1.2 \pm 0.04^{\mathrm{d}}$ & $0.53 \pm 0.028^{d}$ & $03^{c}$ & & $34.0 \pm 2.59^{d}$ \\
\hline \multirow{2}{*}{ Three meals } & 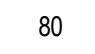 & $1.2 \pm 0.07^{\mathrm{d}}$ & $0.55 \pm 0.0$ & & & $40.9 \pm 4.32$ \\
\hline & 100 & $1.5 \pm 0.08^{\mathrm{e}}$ & $0.67 \pm 0.038^{\mathrm{e}}$ & $9^{d}$ & & 50.3 \\
\hline \multirow{2}{*}{ Four meals } & 80 & $1.3 \pm 0.03^{\mathrm{d}}$ & $0.58 \pm 0$ & 0.11 & & $49.6 \pm 0.99^{e}$ \\
\hline & 100 & $1.6 \pm 0.03^{\mathrm{e}}$ & $0.71 \pm 0.013^{\mathrm{e}}$ & & & $55.7 \pm 2.35^{\mathrm{e}}$ \\
\hline \multicolumn{7}{|c|}{ Two-way ANOVA } \\
\hline \multicolumn{3}{|c|}{ Feeding frequency $(\mathrm{F}) P<0.001$} & 10. & $P<0.001$ & $P<0.001 \quad F$ & $r<0.01$ \\
\hline \multicolumn{2}{|c|}{ Feeding satiation (S) } & 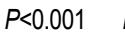 & $P<0.001$ & $P<0.001$ & $P<0.001 \quad F$ & . \\
\hline \multicolumn{2}{|c|}{$F \times S$} & $P<0.4$ & $P<0.4$ & $P<0.2$ & $P<0.003 \quad F$ & $P<0.03$ \\
\hline
\end{tabular}

${ }^{1}$ Values (mean \pm SE of three replications) in the same column not sharing a common superscript are significantly different $(P<0.05)$.

${ }^{2}$ Feed intake (dry matter) $\times 100 /[$ (initial fish wt. + final fish wt. + dead fish wt.) $/ 2 \times$ days fed].

${ }^{3}$ [Body protein (or lipid) gain] $\times 100 /$ protein (or lipid) intake.

일일사료섭취율, 일일단백질섭취율, 일일지질섭취율, 단백 질축적율 및 지질축적율을 Table 2에 나타내었다. 일일사료섭 취율, 일일단백질섭취율 및 일일지질섭취율은 사료 공급 횟수 와 공급율에 모두 영향을 받았다 $(P<0.001)$. 제한 공급구와 만복 공급구에서는 사료 공급 횟수가 증가함에 따라 일일사료 섭취율, 일일단백질섭취율 및 일일지질섭취율이 증가하였으 며, 두 공급율 모두에서 1 일 4회 공급구와 1 일 3 회 공급구와는 유의차가 없었다 $(P>0.05)$. 동일한 공급횟수에서는 일일지질 섭취율에서 1 일 1 회 공급구를 제외하면 일일사료섭취율, 일일 단백질섭취율 및 일일지질섭취율에서 만복 공급구가 제한 공급구보다 유의하게 높은 결과를 나타내었다 $(P<0.05)$. 단백 질축적율 및 지질축적율은 동일한 공급율에서 사료 공급 횟수 가 증가함에 따라 유의하게 증가하였다 $(P<0.05)$. 제한 공급구
에서 단백질축적율 및 지질축적율은 사료 공급 횟수가 증가함 에 따라 유의하게 증가하였다 $(P<0.05)$. 만복 공급구의 경우, 사료 공급 횟수가 증가함에 따라 단백질축적율 및 지질축적율 은 1 일 3 회 공급구까지 증가하였고 1 일 4 회 공급구와는 유의 차가 없었다 $(P>0.05)$. 동일한 공급횟수에서는 1 일 4회 공급구 를 제외하면 단백질축적율 및 지질축적율이 만복 공급구가 제한 공급구보다 유의하게 높은 값을 나타내었다 $(P<0.05)$.

본 연구에서 사료 공급횟수가 증가되면서 일일사료섭취율 이 1 일 3 회까지 증가하다가 더 이상 증가하지 않았는데, 다른 연구결과에서도 이와 유사한 경향이 보고되었다 (Lee et al., 1999). 먹이섭취량이 어느 사료 공급횟수 이상에서 더 이상 증가되지 않는 현상은 그 어종의 사료섭취허용량과 섭취에너 지 요구량 만족 여부와 관련된 것으로 보인다.

Table 3. Proximate composition (\%) of whole body in redand white-colored carp fed diets with different feeding frequency and satiation rate for 6 weeks ${ }^{1}$

\begin{tabular}{lccccc}
\hline $\begin{array}{l}\text { Feeding } \\
\text { frequency/day }\end{array}$ & $\begin{array}{c}\text { Feeding } \\
\text { satiation }(\%)\end{array}$ & Moisture & Crude protein Crude lipid & Ash \\
\hline One meal & 80 & $75.1 \pm 0.35^{\mathrm{d}}$ & $14.6 \pm 0.12^{\mathrm{a}}$ & $6.9 \pm 0.16^{\mathrm{a}}$ & $2.6 \pm 0.09^{\mathrm{c}}$ \\
& 100 & $74.6 \pm 0.38^{\mathrm{d}}$ & $15.0 \pm 0.33^{\mathrm{ab}}$ & $7.8 \pm 0.11^{\mathrm{b}}$ & $2.4 \pm 0.12^{\mathrm{b}}$ \\
& 80 & $73.5 \pm 0.20^{\mathrm{c}}$ & $15.7 \pm 0.27^{\mathrm{b}}$ & $8.1 \pm 0.34^{\mathrm{b}}$ & $2.2 \pm 0.03^{\mathrm{ab}}$ \\
Two meals & 100 & $72.0 \pm 0.48^{\mathrm{b}}$ & $16.0 \pm 0.60^{\mathrm{b}}$ & $9.6 \pm 0.30^{\mathrm{c}}$ & $2.2 \pm 0.10^{\mathrm{ab}}$ \\
& 80 & $71.9 \pm 0.17^{\mathrm{b}}$ & $15.3 \pm 0.07^{\mathrm{ab}}$ & $10.0 \pm 0.13^{\mathrm{cd}}$ & $2.2 \pm 0.02^{\mathrm{ab}}$ \\
Three meals & 100 & $71.8 \pm 0.19^{\mathrm{ab}}$ & $15.3 \pm 0.29^{\mathrm{ab}}$ & $10.5 \pm 0.15^{\mathrm{d}}$ & $2.2 \pm 0.04^{\mathrm{ab}}$ \\
& 80 & $71.4 \pm 0.49^{\mathrm{ab}}$ & $15.7 \pm 0.23^{\mathrm{b}}$ & $10.5 \pm 0.21^{\mathrm{d}}$ & $2.2 \pm 0.05^{\mathrm{ab}}$ \\
Four meals & 100 & $70.8 \pm 0.23^{\mathrm{a}}$ & $15.6 \pm 0.12^{\mathrm{ab}}$ & $10.4 \pm 0.23^{\mathrm{d}}$ & $2.1 \pm 0.10^{\mathrm{a}}$ \\
\hline Two-way ANOVA & & & & & \\
Feeding frequency (F) & $P<0.001$ & $P<0.03$ & $P<0.001$ & $P<0.002$ \\
Feeding satiation (S) & $P<0.02$ & $P<0.5$ & $P<0.001$ & $P<0.2$ \\
F $\times$ S & & $P<0.3$ & $P<0.8$ & $P<0.02$ & $P<0.6$ \\
\hline
\end{tabular}

${ }^{1}$ Values (mean \pm SE of three replications) in the same column not sharing a common superscript are significantly different $(\mathrm{P}<0.05)$.

전어체의 수분, 단백질, 지질 및 회분 함량을 Table 3 에 나타내었다. 전어체의 수분과 지질함량은 사료 공급 횟수 $(P<0.001)$ 와 공급율 $(P<0.02)$ 에 영향을 받았다. 전어체의 단백 질과 회분 함량은 사료의 공급 횟수 $(P<0.05)$ 의 영향을 받았으 나, 공급율에는 영향을 받지 않았다. 전어체의 수분함량은 동일한 공급율에서 사료 공급 횟수가 증가함에 따라 감소하는 경향을 보였다. 동일한 공급횟수에서는 전어체의 수분은 1 일 2회 공급구에서 만복 공급구가 제한 공급구보다 유의하게 낮은 결과를 나타내었다 $(P<0.05)$. 제한 공급구와 만복 공급구 에서는 사료 공급 횟수가 증가함에 따라 전어체 지질함량은 증가하였으며, 두 공급율 모두에서 1 일 4회 공급구와 1 일 3 회 공급구와는 유의차가 없었다 $(P>0.05) .1$ 일 1회 공급구와 1 일 2 회 공급구에서 전어체 지질함량은 만복 공급구가 제한 공급 구보다 유의하게 높았다 $(P<0.05)$. 회분함량은 제한 공급구에 서는 1 일 1 회 공급구가 다른 공급구보다 유의하게 높은 결과 를 나타내었다 $(P<0.05)$. 만복 공급구에서는 1 일 1회 공급구가 
1일 4회 공급구보다 높았다.

본 연구에서 사료의 공급량 및 공급횟수가 감소함에 따라 어체의 지질함량이 낮아지는 결과를 나타내었으며, 1 일 2회 이하의 공급구에서 더욱 뚜렷한 차이를 보여 에너지 공급이 부족하였음을 암시하고 있다. 다른 연구에서도 사료의 공급횟 수 (Dwyer et al., 2002; Wang et al., 1998) 또는 공급율 (Abdelghany and Ahmad, 2002; Bureau et al., 2006; Puvanendran et al., 2003)이 감소하면 어체의 지질함량이 낮아진다고 보고 되었다.

이상의 결과들을 종합하면, 동일한 사료 공급횟수에서 만 복 공급구의 성장이 제한 공급구에 비해 높은 결과를 보인 것으로 보아 비단잉어는 만복으로 사료를 공급하는 것이 더 효율적으로 보인다. 또한, 만복 공급시에도 1 일 4회 공급구까 지 성장이 증가되는 것으로 보아, 평균체중 $6 \mathrm{~g}$ 의 비단잉어 치어를 사육할 때, 사료를 1 일 4 회 만복으로 공급하는 것이 바람직 할 것이라 판단된다.

$$
\text { 사 사 }
$$

본 연구는 국토해양부의 재원으로 한국해양과학기술진흥 원의 지원을 받아 수행된 해양환경기술개발사업 연구임 (No. 20088033-1).

\section{참고문헌}

Abdelghany AE and Ahmad MH. 2002. Effects of feeding rates on growth and production of Nile tilapia, common carp and silver carp polycultured in fertilized ponds. Aquacult Res 33, 415-423.

Biswas G, Jena JK, Singh SK and Muduli HK. 2006a. Effect of feeding frequency on growth, survival and feed utilization in fingerlings of Catla catla (Hamilton), Labeo rohita (Hamilton) and Cirrhinus mrigala (Hamilton) in outdoor rearing systems. Aquacult Res 37, 510-514.

Biswas G, Jena JK, Singh SK and Muduli HK. 2006b. Effect of feeding frequency on growth, survival and feed utilization in mrigal, Cirrhinus mrigala, and rohu, Labeo rohita, guring nursery rearing. Aquaculture 254, 211-218.

Bureau DP, Hua K and Cho CY. 2006. Effect of feeding level on growth and nutrient deposition in rainbow trout (Oncorhynchus mykiss Walbaum) growing from 150 to 600 g. Aquacult Res 37, 1090-1098.

Chapman F, Fitzcoy S, Thunberg E and Adams C. 1997. United States of American trade in ornamental fish. J World Aquacult Soc 28, 1-10.

Cho SH, Jo JY and Kim DS. 2001. Effects of variable feed allowance with constant energy and ratio of energy to protein in a diet for constant protein input on the growth of common carp Cyprinus carpio L. Aquacult Res 32, 349-356.

Company R, Calduch-Giner JA, Kaushik S and Perez-Sanchez J. 1999. Growth performance and adiposity in gilthead sea bream (Sparus aurata): risks and benefits of high energy diets. Aquaculture 171, 279-292.

Duncan DB. 1955. Multiple-range and multiple F tests. Biometrics 11, 1-42.

Dwyer KS, Brown JA, Parrish C and Lall SP. 2002. Feeding frequency affects food consumption, feeding pattern and growth of juvenile yellowtail flounder (Limanda ferruginea). Aquaculture 213, 279-292.

Hancz C, Magyary I, Molnar T, Sato S, Horn P and Taniguchi N. 2003. Evalution of color intensity enhanced by paprika as feed additive in goldfish and koi carp using computer-assisted image analysis. Fish Sci 69, 1158-1161.

Hoff F. 1993. Marine ornamental fish culture. Proceedings of the International Conference, World Aquaculture 1993, Torremolinos, Spain, 298-299.

Hung SSO and Lutes PB. 1987. Optimum feeding rate of hatchery produced juvenile white sturgeon (Acipenser transmontanus) at $20^{\circ} \mathrm{C}$. Aquaculture 65 , 307-317.

Kayano Y, Yao S, Yamamoto S and Nakagawa H. 1993. Effect of feeding frequency on the growth and body constituents of young red-spotted grouper, Epinephelus akaara. Aquaculture 110, 271-278.

Kim KD, Nam MM, Kim KW, Lee HY, Hur SB, Kang YJ and Son MH. 2009. Effects of feeding rate and feeding on growth and body composition of sub-adult flounder Paralichthy olivaceus in subopimal water temperature. Kor J Fish Aquat Sci 42, 262-267.

Lee SM. 1997. Effects of feeding rates on growth, feed efficiency and body composition of the juvenile Korean rockfish (Sebastes schlegeli). Kor J Anim Nutr Feed 21, 327-334.

Lee SM, Seo CH and Cho YS. 1999. Growth of the juvenile olive flounder (Paralichthys olivaceus) fed the diets at different feeding frequencies. J Kor Fish Soc 32, 18-21.

Lee SM, Hwang UG and Cho SH. 2000. Effects of feeding frequency and dietary moisure content on growth, body composition and gastric evacuation of juvenile Korean rockfish (Sebastes schlegeli). Aquaculture 187, 399-409.

Mihelakakis A, Tsolkas C and Yoshimatsu T. 2002. Optimization of feeding rate of hatchery-produced 
juvenile gilthead sea bream Sparus aurata. J World Aquacult Soc 33, 169-175.

$\mathrm{Ng}$ WK, Lu KS, Hashim R and Ali A. 2000. Effects of feeding rate on growth, feed utilization and body composition of a tropical bagrid catfish. Aquacult Int 8, 19-29.

Page JW and Andrews JW. 1973. Interaction of dietary levels of protein and energy on channel catfish (Ictalurus punctatus). J Nutr 103, 1339-1346.

Puvanendran V, Boyce DL and Brown JA. 2003. Food ration requirements of yellowtail flounder Limanda ferruginea (Storer) juveniles. Aquaculture 220, 459-475.

Riche M, Haley DI, Oetker M, Garbrecht S and Garling DL. 2004. Effects of feeding frequency on gastric evacuation and the return of appetite in tilapia Oreochromis niloticus. Aquaculture 234, 657-673.

Ruohonen KJ, Vielman J and Grove DJ. 1998. Effects of feeding frequency on growth and food utilization of rainbow trout (Oncorhynchus mykiss) fed low-fat herring or dry pellets. Aquaculture 165, 111-121.
Seo JY, Lee JH, Kim GU and Lee SM. 2005a. Effect of extruded and moist pellets at different feeding rate on growth and body composition of juvenile flounder, Paralichthys olivaceus. J Aquacult 18, 26-30.

Seo JY, Jang HS, Kim KD, Kim GU and Lee SM. 2005b. Effects of dietary composition, feeding satiation rate and feeding frequency of extruded pellets on growth and body composition of flounder Paralichthy olivaceus. J Aquacult 18, 98-106.

Wang N, Hayward RS and Noltie DB. 1998. Effects of feeding frequency on food consumption, growth size variation, and feeding pattern of age-0 hybrid sunfish. Aquaculture 165, 261-267.

2010년 5월 3일 접수

2010년 6월 1일 수정

2010년 7월 28일 수리 